\title{
Effects of herbivory simulated by clipping and jasmonic acid on Solidago canadensis
}

\author{
Mark van Kleunen, Graziella Ramponi, Bernhard Schmid* \\ Institute of Environmental Sciences, Universität Zürich, Zürich, Switzerland
}

\begin{abstract}
Herbivory is likely to be an important factor in the evolutionary ecology of plants and especially of aggressive invasive species. Because in the introduced range experimental treatment with non-native herbivores is laborious and may be risky for native plants, simulated herbivory by removal of plant tissue and treatment with jasmonic acid, which is a natural elicitor of defences against herbivores, may be a suitable alternative in experimental studies. We studied the effects of removal of $50 \%$ of the leaf area by clipping and of spraying with jasmonic acid on growth, morphology, leaf physiology and reproduction of the invasive Solidago canadensis in Europe. The relative height growth rate was reduced $(-11.9 \%)$ by clipping in the period of day $0-20$ but increased $(+13.5 \%)$ in the period of day 42-138 after start of the treatments. As a consequence, final heights did not differ between treatment and control plants. Clipped plants, however, had thinner stems $(-12.2 \%)$ than unclipped ones. Plants that had been sprayed with jasmonic acid tended to have shorter stem internodes $(-14.7 \%)$, a lower specific leaf area $(-4.6 \%)$, and to delay flowering $(+4.4$ days) than plants that had not been sprayed with jasmonic acid. The biomass of inflorescences was reduced by both clipping $(-43.2 \%)$ and spraying with jasmonic acid $(-32.2 \%)$. Because each, clipping and jasmonic acid, alone only induced some but partly different responses observed in previous studies with natural herbivores, the combined application of both covers the full response spectrum better and should therefore be used as the most realistic simulation of herbivory.
\end{abstract}

Fehlende oder geringe Herbivorie ist ein wahrscheinlicher Erklärungsfaktor für den Erfolg invasiver Pflanzenarten. Da das Einführen von Herbivoren aus dem Ursprungsgebiet zu Versuchszwecken oder zur biologischen Kontrolle mit Gefahren verbunden ist, kann der Einfluss von Herbivoren durch mechanische Entfernung von Pflanzenteilen oder durch die Behandlung mit Jasmonsäure nachgeahmt werden. Jasmonsäure ist ein natürlicher Auslöser von Abwehrreaktionen gegen Herbivoren bei Pflanzen. Wir untersuchten den Einfluss des Entfernens von $50 \%$ der Blattfläche, des Besprühens mit Jasmonsäure oder einer kombinierten Behandlung auf das Wachstum und die physiologischen Eigenschaften der Blätter der invasiven Art Solidago canadensis in Europa. Blattentfernung reduzierte die relative Höhenwachstumsrate der Sprosse um 11.9\% in der Periode von 0-20 Tagen nach der Behandlung aber führte zu einer anschließenden Steigerung um 13.5\% in der Periode von 42-138 Tagen, so dass die Endhöhe der Pflanzen durch diese simulierte Herbivorie nicht beeinflusst war. Behandlung mit Jasmonsäure führte zu verkürzten Stengelinternodien $(-14.7 \%)$, verkleinerter Blattfläche $(-4.6 \%)$ und verzögerter Blütezeit (+4.4 Tage). Die Infloreszenzbiomasse wurde durch die Blattentfernung um 43.2\% und die Jasmonatbehandlung um 32.2\% reduziert. Da die beiden Behandlungsfaktoren das Pflanzenwachstum unabhängig voneinander und in unterschiedlicher Weise beeinflussten und die beobachteten Pflanzenreaktionen in der Summe den in der

*Corresponding author: Bernhard Schmid, Institut für Umweltwissenschaften, Universität Zürich, Winterthurerstr. 190, CH 8057 Zürich, Switzerland, Phone: ++41-1-635-5205, Fax: ++41-1-635-5711, E-mail bschmid@uwinst.unizh.ch 
Literatur beschriebenen Reaktionen auf natürliche Herbivorie entsprachen, kann die Kombination von mechanischer und chemischer Behandlung als optimale Simulation von Herbivorie bei $S$. canadensis und möglicherweise anderen invasiven Arten betrachtet werden.

Key words: defoliation - invasive species - jasmonate - morphology - physiology - Solidago altissima

\section{Introduction}

Herbivory may affect the morphology, physiology, growth and reproduction of plants, and as a consequence it is likely to be an important factor in the evolutionary ecology of plants (Crawley 1983, Hilker and Dicke 2003). The absence of natural herbivores may give introduced plants a competitive advantage over native plants (Blossey \& Nötzold 1995). This suggests that the expansion of agressive invasive species may be reduced by introducing their natural herbivores in the new range (McEvoy et al. 1991, Kirby et al. 2000). However, because these herbivores may also have detrimental effects on native plants, introducing them may be risky (Louda et al. 1997, Fowler et al. 2000). Therefore, an initial low-risk step in studying potential effects of herbivores on invasive plants would be to simulate herbivory by clipping of leaves or by other mechanical damage of plant tissue. However, factors in the salivary and oviposition fluids of the herbivores may induce or suppress physiological defence responses against herbivores in addition to the ones induced by the loss of plant tissue (Felton \& Eichenseer 1999, Musser et al. 2002). Therefore, clipping alone may not fully mimic natural herbivory (Baldwin 1990, 1996, Meyer 1993, Agrawal 1999, Agrawal et al. 1999, Felton \& Eichenseer 1999).

Jasmonic acid is a natural elicitor of chemical defences against herbivores, and treatment of plants with jasmonic acid or with the volatile methyl jasmonate appears to be a good method to induce responses similar to the ones induced by natural herbivores (Baldwin 1996). Therefore, treatment with jasmonic acid allows for separation of the effects of leaf-area loss due to herbivory from the indirect effect of induced defences on plant performance (Baldwin 1996, Agrawal et al. 1999, Thaler 1999). So far, effects of jasmonic acid on plants have mainly been studied with regard to the defence chemistry while its effects on growth and reproduction got less attention (Baldwin 1996, Agrawal et al. 1999, Thaler 1999). Moreover, there is only limited information on whether leaf-area removal and treatment with jasmonic acid have synergistic or antagonistic effects on plant characteristics.

In a factorial design, we tested whether jasmonic acid in addition to leaf-area removal affects the height growth, and sexual and vegetative reproduction of
Solidago canadensis, which is invasive in Europe. In its native range in North America, eruptions of densities of herbivorous insects may result in severe defoliation of plants of this species (McBrien et al. 1983, Root \& Cappuccino 1992). Moreover, its abundance in natural habitats increases when herbivorous insects are excluded by using an insecticide (Cain et al. 1991, Carson \& Root 2000). This suggests that herbivory is an important factor in the evolutionary ecology of this species. Because growth of plants is determined by their architecture/morphology and ecophysiology, we additionally studied effects of simulated herbivory on stem diameter, internode length, leaf size, specific leaf area, stomatal conductance and leaf nitrogen content.

\section{Materials and methods}

\section{Study species}

Taxa of the Solidago canadensis L. species complex are rhizomatous perennials that occur over a large range in North America from Arizona, Texas and Florida in the south to Nova Scotia in the north (Scoggan 1979, Semple 1992). The rank of these taxa is difficult to define, two important groups having been referred to as $S$. canadensis L. s.str. (predominantly $2 \times=2 n=18$ ) and as $S$. canadensis var. scabra Torr. \& Gray $=S$. altissima L. (Croat 1972, Melville \& Morton 1982, Schmid et al. $1988 \mathrm{a}$; predominantly $6 x=2 n=54)$. Plants with the morphology of var. scabra (Schmid et al. 1988a, Weber 1994), but with diploid cytotypes, found more commonly in $S$. canadensis s.str., have been introduced into Europe in the $17^{\text {th }}$ century (Wagenitz 1964, Schmid \& Weiner 1993, Weber \& Schmid 1993). This taxon presently ranges from northern Italy in the south to southern Scandinavia in the north and from Ireland in the west to Russia in the east (Weber 2000) and is considered to be one of the most aggressive invading species in Europe (Zwölfer 1976, Weber \& Schmid 1993). Moreover, the species has also been introduced to Asia and Australia (Weber 2000). In view of the complicated unresolved taxonomy and the multiple ploidy levels within the taxa, we collectively refer to the species complex with the binary name $S$. canadensis s.l., omitting the "s.l." for simplicity.

Solidago canadensis grows mainly in disturbed sites such as in abandoned fields and along roads and rail- 
roads. Aboveground shoots of plants of $S$. canadensis are produced annually from a perennial branched rhizome system. In central Europe, shoots can rise to $2 \mathrm{~m}$ in height, produce up to $20 \mathrm{~cm}$ long lanceolate leaves, and end up in a branched inflorescence (Weber 2000). The species is self-incompatible (Schmid \& Dolt 1994) and flowers in the period from mid-July to end of October. Inflorescences consist of numerous flower heads along up to 60 short, recurved branches that are produced from the axils of leaves along the upper part of the main stem (Weber 2000). Flower heads consist of 5-15 female ray florets and 3-9 hermaphroditic disc florets, and are visited by several insect species (Weber 2000). One single inflorescence may produce more than 10000 mainly wind-dispersed seeds (VoserHuber 1983, Meyer \& Schmid 1991).

\section{Plant material and precultivation}

On 10 April 2001, we took cuttings (3-10 cm long shoots connected to $1-3 \mathrm{~cm}$ of rhizome) of randomly chosen plants (i.e., clones) in a 1-y old artificial population founded from plants representing 20 seed families of each of 9 European and 10 North American populations of $S$. canadensis. Therefore, the plant material in this study represents a comprehensive sample of genetic material from both the native and introduced range of this species complex. Because in this study we only wanted to focus on the responses to leaf-area removal and jasmonic acid, we did not study differences between plants from the different populations and continents. The cuttings were planted in $4 \mathrm{~cm} \times 4 \mathrm{~cm} \times 5 \mathrm{~cm}$ holes of multipot trays filled with commercial potting compost. The trays were placed in a garden bench covered with transparent plastic plates to raise the temperature and humidity which promote root development of the cuttings.

\section{Experimental set-up}

On 31 May 2001, we randomly assigned 64 rooted cuttings to positions within two rows along the two long sides of a $14.2 \mathrm{~m} \times 16.2 \mathrm{~m}$ experimental field in the garden of the Institute at the University of Zürich, Switzerland. Each row was partitioned into eight 0.9-m long subplots with $1 \mathrm{~m}$ distance between them. On 12 June 2001, the four plants within each subplot were randomly assigned to the four treatments: (1) control, (2) jasmonic acid, (3) clipping, and (4) clipping and jasmonic acid. At the start of the experiment, when plants were about $15 \mathrm{~cm}$ in height, we removed with scissors the distal half of each leaf of the plants in the clipping treatments (treatments 3 and 4), and sprayed the plants in the jasmonic acid treatments (treatments 2 and 4 ) with a $1 \mathrm{mM}$ jasmonic acid
(Sigma Chemical Co., St Louis, Missouri, USA) solution until they were dripping. This concentration is within the range of concentrations used by Thaler et al. (1996) to induce chemical defences in Lycopersicon esculentum without being toxic to the plant. Jasmonic acid was first dissolved in methanol and subsequently diluted with distilled water to the required concentration. Plants that were not in the jasmonic acid treatments (treatments 1 and 3) were sprayed with the solvent until dripping. Treatments were repeated after four weeks. One plant was removed from the final data set because it was another Solidago species, and two plants were excluded from part of the data set because they had been damaged during the experiment.

\section{Measurements}

For determination of relative height growth rates, we measured the height of each plant one day before (referred to as day 0 ), and 20,42 and 138 days after the start of the experiment. Relative height growth rates were calculated as the difference between two consecutive In-transformed height measurements divided by the number of days between the two measurements (Meyer 1998a). As measures of shoot architecture or morphology, we measured 41 days after the start of the experiment on each plant the basal stem width and the combined length of the three internodes between the fifth and eight unfolded leaf counted from the shoot tip (Schmid \& Bazzaz 1994). Moreover, we harvested the fifth leaf, determined its area with a CI-202 Area Meter (CID Inc., Camas, Wa, USA), and weighed it after drying to constant mass at $70^{\circ} \mathrm{C}$. As physiological leaf characteristics, we calculated the specific leaf area of the fifth leaf by dividing its area by its mass, and determined its nitrogen content with a CHNS-analyser (CHNS-932, LECO corporation, St. Joseph, Mi, USA). On 24 July 2001 (42 days after the start of the experiment), we measured the stomatal conductance of each plant on the sixth leaf counted from the shoot tip with a porometer (AP4, Delta-T Devices Ltd., Cambridge, UK). All measurements of stomatal conductance were done within one hour in the early afternoon. The sky was slightly overcast and the temperature was ca. $23^{\circ} \mathrm{C}$. To study effects of simulated herbivory on flowering phenology, we noted every second day which plants started to flower. As estimate of sexual reproductive effort, we harvested the inflorescences (i.e., the branches bearing the flower heads) at the end of the growing season before they started to shed their seeds, and weighed them after drying to constant mass at $70^{\circ} \mathrm{C}$. As estimate of vegetative reproductive effort, we counted the number of vegetative offspring (number of shoots) of each plant on 3 April 2002. 


\section{Analyses}

All variables were analysed with analyses of variance using the statistical software SPSS (SPSS Inc, Chicago, Illinois, USA). Clipping treatment and jasmonic acid treatment were considered as fixed factors, and rows and subplots within rows as random factors. The inflorescence biomass and leaf area were $\log 10$-transformed prior to analyses to achieve normality and homoscedasticity. Changes over time in relative height growth rates of plants were analysed with repeatedmeasures analysis of variance. To have two independent estimates of the relative height growth rate over time (Poorter 1989, see also Egli \& Schmid 2001), we only included the growth rates during the period of day $0-20$ and the ones during the period of day $42-138$ in this analysis. The between-subjects effects refer to plants, and the within-subject effects refer to the two census periods.

\section{Results}

\section{Growth and morphology of shoots}

The relative height growth rate of plants was on average $0.031 \mathrm{~cm} \mathrm{~cm}^{-1}$ day $^{-1}$ in the period of days $0-20$ and decreased to $0.009 \mathrm{~cm} \mathrm{~cm}^{-1}$ day $^{-1}$ by the period of days 42-138 (Fig. 1). Plants that had been clipped had a lower relative height growth rate $(-11.9 \%)$ in the first

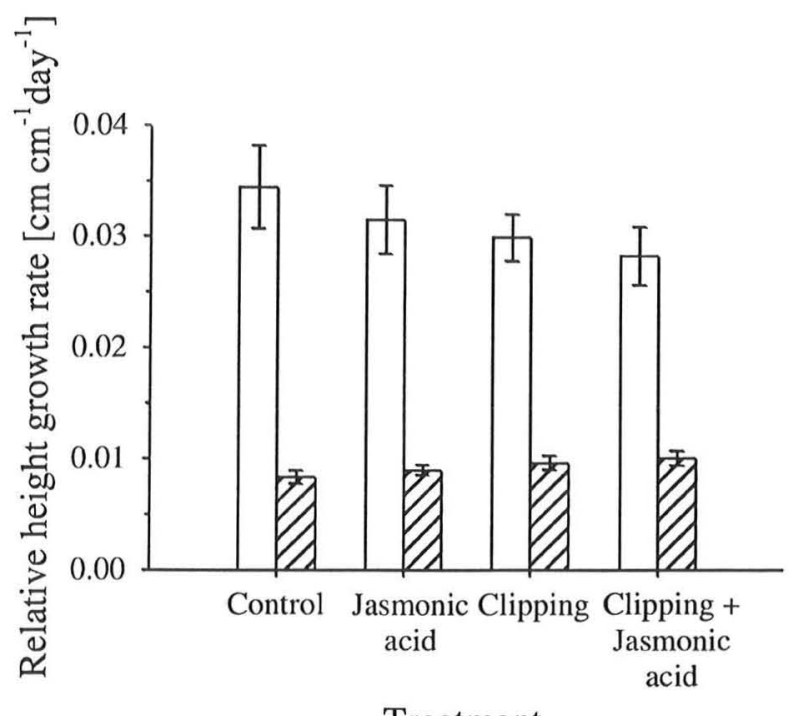

Treatment

Fig. 1. The effects of clipping, spraying with jasmonic acid, and census period on the mean relative height growth rate in the experiment with plants of the Solidago canadensis complex. Census periods were day 1-20 (open bars) and day 42-138 (hatched bars) after treatment application. Parameter estimates are given $\pm 1 \mathrm{SE}$. period and a higher one $(+13.5 \%)$ in the second period than plants that had not been clipped (Fig. 1). This was reflected in a marginally significant period-byclipping interaction $\left(\mathrm{F}_{1,42}=3.98, P=0.053\right)$. As a consequence, there were no significant differences in shoot height between plants in the different simulated herbivory treatments at the end of the growing season (clipping: $\mathrm{F}_{1,42}=0.66, P=0.422$; jasmonic acid: $\mathrm{F}_{1,42}=$ $0.15, P=0.697$; Fig. 2a).

Plants that had been clipped had a smaller basal stem diameter $\left(-12.2 \% ; F_{1.43}=18.72, P<0.001\right)$ than plants that had not been clipped (Fig 2b). The leaf area was smallest for plants which were both clipped and sprayed with jasmonic acid (-23.8\% when compared to control; $\mathrm{t}_{28}=1.96, P=0.060$ ) although none of the treatment effects or their interaction was statistically significant (clipping: $F_{1,43}=1.66, P=0.205$; jasmonic acid: $F_{1,43}=1.47, P=0.232$; clipping-by-jasmonic acid interaction: $\mathrm{F}_{1,43}=1.67, P=0.203$; Fig. $2 \mathrm{c}$ ). Plants that had been sprayed with jasmonic acid had marginally shorter stem internode lengths $\left(-14.7 \% ; F_{1,43}=3.18\right.$, $P=0.082)$ than plants that had not been sprayed with jasmonic acid (Fig. 2d).

\section{Physiological leaf characteristics}

Plants that had been sprayed with jasmonic acid had a marginally lower specific leaf area $\left(-4.6 \% ; F_{1.43}=\right.$ 3.01, $P=0.090)$ than plants that had not been sprayed with jasmonic acid (Fig. 2e). The nitrogen content of the leaves did not significantly differ between plants in the different treatments (clipping: $\mathrm{F}_{1,42}=0.14, P=$ 0.710 ; jasmonic acid: $F_{1,42}=0.58, P=0.452$; Fig. 2f). The same was true for the stomatal conductance (clipping: $\mathrm{F}_{1,42}=1.44, P=0.237$; jasmonic acid: $\mathrm{F}_{1,42}=$ $0.38, P=0.541$; Fig. $2 \mathrm{~g}$ ), although plants that had been clipped tended to have a slightly higher stomatal conductance than plants that had not been clipped.

\section{Flowering phenology and sexual and vegetative reproduction}

Most plants started flowering in September, and plants that had been sprayed with jasmonic acid tended to flower later than plants that had not been sprayed with jasmonic acid, although this effect was statistically not significant $\left(\mathrm{F}_{1.41}=1.82, P=0.185\right.$; Fig. $\left.2 \mathrm{~h}\right)$. Plants that had been clipped had smaller inflorescences $\left(-43.2 \% ; \mathrm{F}_{1.40}=8.30, P=0.006\right)$ than plants that had not been clipped (Fig. 2i). In addition, plants that had been sprayed with jasmonic acid had smaller inflorescences $\left(-32.2 \% ; F_{1,40}=5.03, P=0.031\right)$ than plants that had not been sprayed with it (Fig. 2i).

Unclipped plants that had been sprayed with jasmonic acid produced $28.9 \%$ fewer vegetative off- 
A

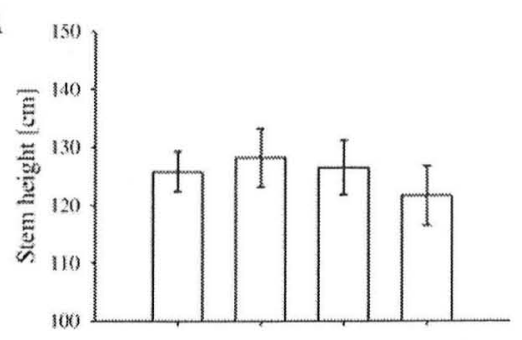

C

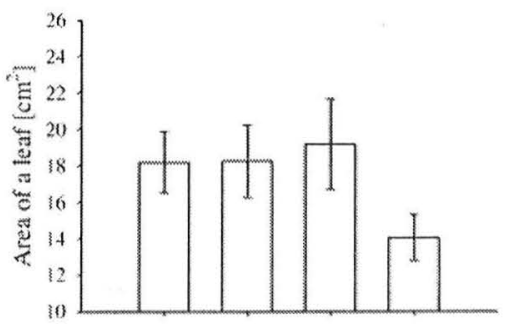

E

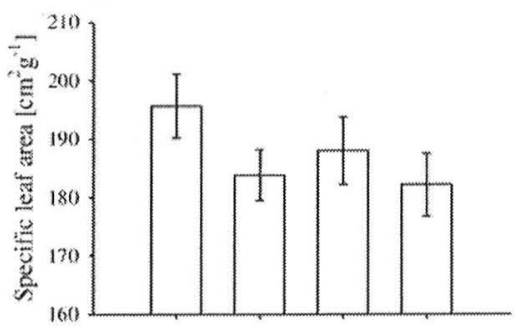

G

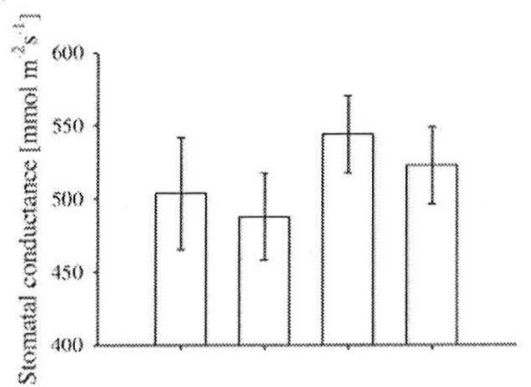

Fig. 2. The effects of clipping and spraying with jasmonic acid on the mean (a) final stem height (b) basal stem width, (c) area of a leaf, (d) internode length, (e) specific leaf area, (f) nitrogen content per unit leaf area, (g) stomatal conductance, (h) flowering phenology, (i) inflorescence biomass, and (j) the number of vegetative offspring in the experiment with plants of the Solidago canadensis complex. Parameter estimates are given \pm 1 SE for non-transformed data, and \pm upper and lower SE for log-transformed data after back transformation.

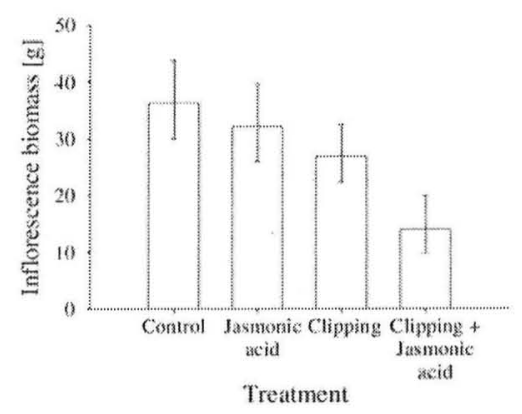

B

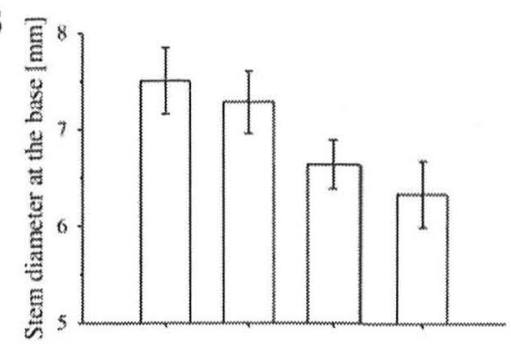

D

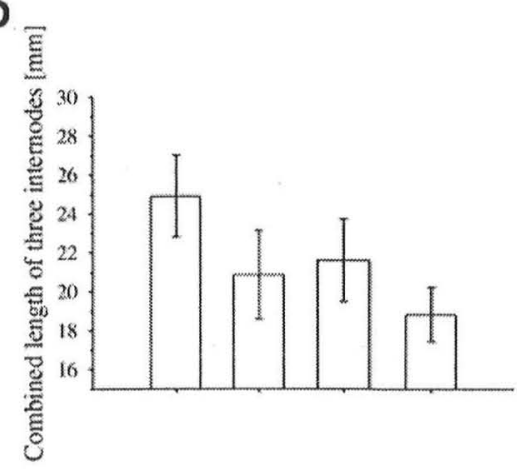

$\mathrm{F}$

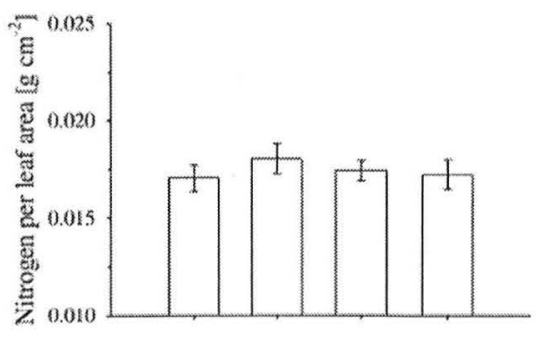

$\mathrm{H}$

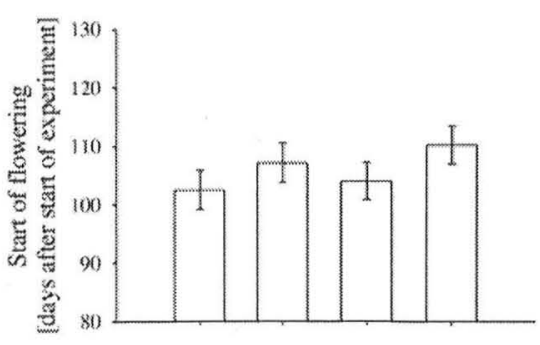

J

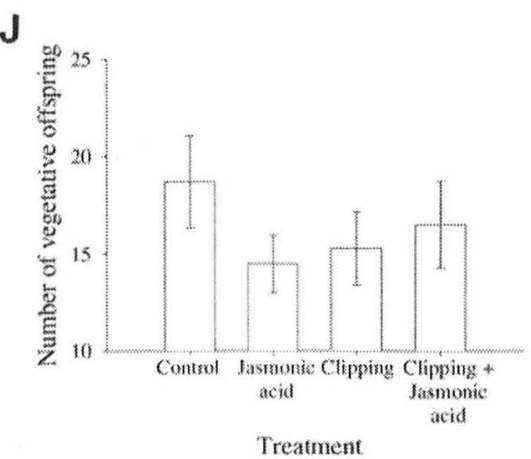


spring than the unclipped control plants, while clipped plants that had been sprayed with jasmonic acid produced $8.2 \%$ more vegetative offspring than the clipped control plants (Fig. 2j). Neither the effect of spraying with jasmonic acid $\left(\mathrm{F}_{1,42}=0.24, P=0.628\right)$ nor the clipping-by-jamonic acid interaction $\left(\mathrm{F}_{1.42}=1.46, P=\right.$ 0.233), however, was significant.

\section{Discussion}

\section{Effects of clipping and jasmonic acid on growth and morphology of shoots}

Relative height growth rate was reduced by leaf-area removal during the first weeks of the experiment but thereafter it was increased. As a consequence, the height of plants at the end of the growing season was not different between the simulated herbivory treatments. Stem diameters, however, were reduced in plants that had been clipped which indicates that the higher relative height growth rate after leaf-area removal at the end of the growing season was at a cost of mechanical strength. In two experiments with plants from a North American population of $S$. altissima (i.e., S. canadensis var. scabra), Meyer (1998a,b) also found first a lower and later a higher relative height growth rate in plants that had been defoliated by clipping or by a leaf chewing beetle. Moreover, in one of these studies (Meyer 1998a), the compensated height growth in plants defoliated by a beetle was also at a cost of stem diameter. Because the plants in our experiment were not grown in dense stands, and the plants in the studies of Meyer $(1998 a, b)$ were grown singly in pots, it is not likely that the shoots of clipped plants had elongated in response to shading by neighbouring unclipped plants. This is also suggested by the results of a previous study with $S$. altissima, in which height growth was overcompensated after clipping (Schmid et al. 1988b).

Height growth of plants was not affected by spraying them with jasmonic acid. Plants which had been sprayed with jasmonic acid, however, had shorter internodes, and plants that had been both clipped and sprayed with jasmonic acid tended to have smaller leaves. Two other studies, however, found that newly grown leaves of $S$. altissima were larger after plants had been defoliated by clipping (Schmid et al. 1988b) or by a leaf chewing beetle (Meyer 1998a), although in the second study this effect was not significant. For $S$. canadensis sensu stricto, however, Schmid et al. (1988b) found that leaf sizes decreased after defoliation by clipping. This suggests that jasmonic acid may affect the morphology of $S$. canadensis in addition to the effects of leaf-area removal. Moreover, it may sug- gest that these effects are not necessarily the same as the ones of defoliation by natural herbivores. On the other hand, it may also suggest that there is variation among genotypes and among taxa of the $S$. canadensis complex in responses to herbivory, and thus that results based on fewer genotypes or populations than used in the present study may not be representative for this variable species complex.

\section{Effects of clipping and jasmonic acid on physiological leaf characteristics}

Plants that had been defoliated by clipping tended to have a slightly but non-significantly higher stomatal conductance than the unclipped ones. This may suggest that in response to leaf-area removal, plants increase gas exchange and as a consequence have a higher rate of photosynthesis. The nitrogen content of the leaves was neither affected by leaf-area removal nor by spraying with jasmonic acid. Because the nitrogen content of leaves is generally highly correlated with the light-saturated rate of photosynthesis (Björkman 1981, Hirose \& Werger 1994), the results indicate that the maximum photosynthetic capacity was not affected by simulated herbivory. Meyer (1998b) found that both stomatal conductance and light saturated rates of photosynthesis of $S$. altissima had increased in newly produced leaves 16 days after defoliation. However, in another study, Meyer (1998a) found that light-saturated rates of photosynthesis of $S$. altissima had only increased in the leaves that had remained after defoliation by a leaf-chewing beetle but not in the newly grown ones.

We did not find significant effects of spraying with jasmonic acid on the stomatal conductance and nitrogen content of leaves. The specific leaf area, however, tended to be lower for plants that had been sprayed with jasmonic acid than for plants without it. A similar response was found in $S$. altissima when they had been attacked by xylem-sap feeding or leaf-chewing insects (Meyer 1993). This suggests that jasmonic acid induced the formation of tougher, less palatable leaves, and may thus be an adaptive response to herbivory (Choong 1996). In another study, however, Meyer (1998a) found an increase in the specific leaf area of $S$. altissima after defoliation by a leaf-chewing beetle and additional clipping. Also Meyer (1998b) found an increased specific leaf area after clipping in $S$. altissima.

\section{Effects of clipping and jasmonic acid on flowering phenology and sexual and vegetative reproduction}

Both leaf-area removal and jasmonic acid had negative effects on plant performance, suggesting that herbivores may be used to reduce the expansion of this in- 
vasive species in Europe. Although leaf-area removal did not affect the start of flowering, it reduced the size of inflorescences. A similar response of inflorescence biomass to clipping was found in plants of a North American population of $S$. altissima (Meyer 1998b). Spraying with jasmonic acid also resulted in smaller inflorescences. In plants of a North American population of $S$. altissima, natural herbivory by a leaf-chewing beetle and a xylem-sap feeding spittlebug also resulted in smaller inflorescences (Meyer \& Root 1993, Meyer 1998a). Moreover, Meyer \& Root (1993) did not find an effect of natural herbivory on the rhizome biomass of $S$. altissima, which is in line with our result that there is no consistent effect of leaf-area removal or jasmonic acid on vegetative reproduction. This suggests that clipping alone may only mimic part of the effects of natural herbivory, and additional spraying with jasmonic acid does better mimic natural herbivory.

Although negative effects of jasmonic acid or its volatile methyl jasmonate on fitness are not always found or not for all fitness components to the same degree (Agrawal et al. 1999, Thaler 1999, Cipollini \& Sipe 2001), they have also been reported for some other species. Treatment with methyl jasmonate reduced seed production in Nicotiana attenuata (Baldwin 1998), and treatment with jasmonic acid reduced pollen production and delayed flowering in Raphanus raphanistrum (Agrawal et al. 1999) and seed production in Arabidopsis thaliana (Cipollini 2002). Effects of jasmonic acid may also depend on its concentration as found in Lycopersicon esculentum in which the same concentration as used in our study delayed fruit set while a 10 -fold concentration additionally reduced fruit and seed set (Redman et al. 2001). This result, however, may also have been a consequence of phytotoxic effects of the high jasmonic acid concentration used in that study (Thaler et al. 1996, Oka et al. 1999). The effects of jasmonic acid may also become more apparent when induced plants are grown in competition with non-induced ones, as found in Nicotiana attenuata (van Dam \& Baldwin 1998, 2001). In these studies, negative effects of jasmonic acid on fitness components were interpreted as evidence for costs of induced defence chemistry. In Solidago species, the most important defence compounds against herbivores are likely to be diterpenoids (Cooper-Driver \& LeQuesne 1987) or phenolics (Abrahamson et al. 1991). Rahm (2003) found evidence for increased levels of the polyphenolic chlorogenic acid in $S$. canadensis after herbivory by slugs, indicating induced defence mechanisms in this species. Moreover, when we assume that there were no phytotoxic effects of jasmonic acid, its negative effect on sexual reproduction in our experiment also suggests that $S$. canadensis has in- duced defence chemistry and its associated costs (Cipollini et al. 2003).

\section{Interactions between clipping and jasmonic acid}

Relative height growth rate and basal stem diameter were affected by leaf-area removal only, while internode length and the specific leaf area were affected by jasmonic acid only. The inflorescence biomass, however, was affected by both leaf-area removal and jasmonic acid, indicating that responses to leaf-area removal and jasmonic acid can act additively in the same direction rather than antagonistically. In Raphanus raphanistrum, the separate effects of clipping and jasmonic acid on induced chemical defences and fitness components summed to the effect of natural herbivory by caterpillars (Agrawal et al. 1999). In Nicotiana attenuata, the combination of methyl jasmonate and clipping had an even stronger effect than the sum of each treatment separately (van Dam \& Baldwin 2001). Although in our study, the effect of jasmonic acid on leaf size and the production of vegetative offspring seemed to depend on leaf-area removal, interactions between clipping and jasmonic acid were statistically not significant.

\section{Conclusions}

Some traits were affected by clipping only, others were affected by jasmonic acid only and some were affected by both. This indicates that simulation of herbivory by both clipping and spraying with jasmonic acid results in a broader response pattern to simulated herbivory than clipping only. It has, however, recently been suggested that exogenously applied jasmonic acid may have different effects than natural endogenous jasmonic acid (Heil \& Baldwin 2002). Therefore, to more fully test the suitability of jasmonic acid as a treatment to mimic herbivory, experiments are required that directly compare controlled natural herbivory with a treatment of both clipping and spraying with jasmonic acid. However, because each, clipping and jasmonic acid, alone only induced some but partly different fitness responses observed in previous studies with natural herbivores, the combined application of both covers the full response spectrum better and should therefore be used as the most realistic simulation of herbivory.

Acknowledgements. We thank Ewald Weber for providing and coordinating the collection of the seed material, Maria Uriarte, Amy Whipple, Shellee Morehead, Lauren Young, Mark Bremer, Jim Cronin, Stephen Heard, Gabi Jakobs, Gretchen Meyer, Ewald Weber, Hansjörg Dietz, Bev- 
erly Rathcke and Richard Root for collecting seeds, René Husi for doing the nitrogen analysis, Theres Zwimpfer, Andrea Lienert, Rebecca Göpfert, Claudia Pfister, Patricia Meier, Lukas Wotruba, Steve Deubelbeiss and Rene Oertli for practical assistance, and Kristin Lewis and Anurag Agrawal for helpful comments on earlier drafts of this ms.

\section{References}

Abrahamson WG, McCrea KD, Whitwell AJ, Vernieri LA (1991) The role of phenolics in goldenrod ball gall resistance and formation. Biochemical Systematics and Ecology 19: 615-622.

Agrawal AA (1999) Induced responses to herbivory in wild radish: effects on several herbivores and plant fitness. Ecology 80: 1713-1723.

Agrawal AA, Straus SY, Stout MJ (1999) Costs of induced responses and tolerance to herbivory in male and female fitness components of wild radish. Evolution 4: 1093-1104.

Baldwin IT (1990) Herbivory simulations in ecological research. Trends in Ecology and Evolution 5: 91-93.

Baldwin IT (1996) Methyl jasmonate-induced nicotine production in Nicotiana attenuata: induced defenses in the field without wounding. Entomologia Experimentalis et Applicata 80: 213-220.

Baldwin IT (1998) Jasmonate-induced responses are costly but benefit plants under attack in native populations. Proceedings of the National Academy of Science of the United States of America 95: 8113-8118.

Björkman O (1981) Responses to different quantum flux densities. In: Lange OL, Nobel PS, Osmond GB, Ziegler H (eds) Encyclopedia of plant physiology, New Series, Vol 12A: Physiological plant ecology I: Responses to physical environment. Spring, New York, pp 57-107.

Blossey R, Nötzold R (1995) Evolution of increased competitive ability in invasive nonindigenous plants: a hypothesis. Journal of Ecology 83: 887-889.

Cain ML, Carlson WP, Root RB (1991) Long-term suppression of insect herbivores increases the production and growth of Solidago altissima herbivores. Oecologia 88 : 251-257.

Carson WP, Root RB (2000) Herbivory and plant species coexistence: community regulation by an outbreaking phytophagous insect. Ecological Monographs 70: 73-99.

Choong MF (1996) What makes a leaf tough and how this affects the pattern of Caslanopsis fissa leaf consumption by caterpillars. Functional Ecology 10: 668-674.

Cipollini DF (2002) Does competition magnify the fitness costs of induced responses in Arabidopsis thaliana? A manipulative approach. Oecologia:131 514-520.

Cipollini DF, Sipe ML (2001) Jasmonic acid treatment and mammalian herbivory differentially affect chemical defenses and growth of wild mustard (Brassica kaber) Chemoecology 11: 137-143.

Cipollini D, Purrington CB, Bergelson J (2003) Costs of induced responses in plants. Basic and Applied Ecology 4: $79-85$

Cooper-Diver GA, LeQuesne PW (1987) Diterpenoids as insect antifeedants and growth inhibitors: role in Solidago species. In: Waller GR (ed) Allelochemicals: role in agriculture and forestry. 190th Meeting of American Chemical Society, Washington, pp 534-550.

Crawley MJ (1983) Herbivory. The dynamics of animalplant interactions. Blackwell Scientific Publications, Oxford.

Croat T (1972) Solidago canadensis complex of the Great Plains. Brittonia 24: 317-326.

Egli P, Schmid B (2001) The analysis of complex leaf survival data. Basic and Applied Ecology 2: 223-231.

Felton GW, Eichenseer H (1999) Herbivore saliva and its effects on plant defense against herbivores and pathogens. In: Agrawal AA, Tuzun S, Bent E (eds) Inducible plant defenses against pathogens and herbivores: Biochemistry, ecology, and agriculture. American Phytopathological Society Press, St. Paul, pp 19-36.

Fowler SV, Syrett P, Hill RL (2000) Success and safety in the biological control of environmental weeds in New Zealand. Australian Ecology 25: 553-562.

Heil M, Baldwin IT (2002) Fitness costs of induced resistance: emerging experimental support for a slippery concept. Trends in Plant Science 7: 61-67.

Hilger M, Dicke M (2003) Induced plant responses towards herbivory. Basic and Applied Ecology 4:1-2.

Hirose T, Werger MJA (1994) Photosynthetic capacity and nitrogen partitioning among species in the canopy of a herbaceous plant community. Oecologia 100: 203-212.

Kirby DR, Carlson RB, Krabbenhoft KD, Mundal D, Kirby MM (2000) Biological control of leafy spurge with introduced flea beetles (Aphthona spp.). Journal of Range Management 53: 305-308.

Louda SM, Kendall D, Connor J, Simberloff D (1997) Ecological effects of an insect introduced for the biological control of weeds. Science 277: 1088-1090.

McBrien H, Harmsen R, Crowder A (1983) A case of insect grazing affecting plant succession. Ecology 64: 1035-1039.

McEvoy P, Cox C, Coombs E (1991) Successful biologicalcontrol of ragwort, Senecio jacobaea, by introduced insects in Oregon. Ecological Applications 1: 430-442.

Melville MR, Morton JK (1982) A biosystematic study of the Solidago canadensis (Compositae) complex. I. The Ontario populations. Canadian Journal of Botany 60: 976-997.

Meyer AH, Schmid B (1991) Experimentelle Demographie von Pflanzen: Solidago altissima. In: Schmid B, Stöcklin J (eds) Populationsbiologie der Pflanzen. Birkhäuser, Basel, pp 123-146.

Meyer GA (1993) A comparison of the impacts of leaf- and sap-feeding insects on growth and allocation of goldenrod. Ecology 74: 1101-1116.

Meyer GA (1998a) Mechanisms promoting recovery from defoliation in goldenrod (Solidago altissima). Canadian Journal of Botany 76: 450-459.

Meyer GA (1998b) Pattern of defoliation and its effects on photosynthesis and growth of goldenrod. Functional Ecology 12: 270-279.

Meyer GA, Root RB (1993) Effects of herbivorous insects and soil fertility on reproduction of goldenrod. Ecology 74: 1117-1128. 
Musser, RO, Hum-Musser SM, Eichenseer H, Peiffer M, Ervin G, Murphy JB, Felton GW (2002) Caterpillar saliva beats plant defences. Nature 416: 599-600.

Oka Y, Cohen Y, Spiegel Y (1999) Local and systemic induced resistance to the root-knot nematode in tomato by DL-beta-Amino-n-butyric acid. Phytopathology 89: $1138-1143$.

Poorter H (1989) Plant growth analysis: towards a synthesis of the classical and functional approach. Physiologia Plantarum 75: 237-244.

Rahm S (2003) Comparison of invasive European and native American taxa of the $S$. canadensis complex, in respect to some taxonomic features and their response to herbivory. Diploma thesis, University of Zurich, Zurich.

Redman AM, Cipollini DF, Schultz JC (2001) Fitness costs of jasmonic acid-induced defence in tomato, Lycopersicon esculentum. Oecologia 126: 380-385.

Root RB, Cappuccino N (1992) Patterns in populationchange and the organization of the insect community associated with goldenrod. Ecological Monographs 62: 393-420.

Schmid B, Bazzaz FA (1994) Crown construction, leaf dynamics, and carbon gain in 2 perennials with contrasting architecture. Ecological Monographs 64: 177-203.

Schmid B, Dolt, C (1994) Effects of maternal and paternal environment and genotype on offspring phenotype in Solidago altissima L. Evolution 48: 1525-1549.

Schmid B, Weiner J (1993) Plastic relationships between reproductive and vegetative mass in Solidago altissima. Evolution 47: 61-74.

Schmid B, Puttick GM, Burgess KH, Bazzaz FA (1988a) Correlations between genet architecture and some life history features in three species of Solidago. Oecologia 75: 459-464.

Schmid B, Puttick GM, Burgess KH, Bazzaz FA (1988b) Clonal integration and effects of simulated herbivory in old-field perennials. Oecologia 75: 465-471.
Scoggan HJ (1979) The flora of Canada. National Museum of Natural Sciences, Publications in Botany 7: 1117-1711.

Semple JC (1992) A geographic summary of chromosome number reports for North American asters and goldenrods (Asteraceae: Astereae). Annals of Missouri Botanical Garden 79: 95-109.

Thaler JS (1999) Induced resistance in agricultural crops: effects of jasmonic acid on herbivory and yield in tomato plants. Environmental Entomology 28: 30-37.

Thaler JS, Stout MJ, Karban R, Duffey SS (1996) Exogenous jasmonates simulate insect wounding in tomato plants (Lycopersicon esculentum) in laboratory and field. Journal of Chemical Ecology 22: 1767-1781.

van Dam NM, Baldwin IT (1998) Costs of jasmonate-induced responses in plants competing for limited resources. Ecology Letters 1: 30-33.

van Dam NM, Baldwin IT (2001) Competition mediates costs of jasmonate-induced defences, nitrogen acquisition and transgenerational plasticity in Nicotiana attenuata. Functional Ecology 15: 406-415.

Voser-Huber ML (1983) Studien an eingebürgerten Arten der Gattung Solidago L. Dissertationes Botanicae 68, Cramer, Vaduz, Liechtenstein.

Wagenitz G (1964) Solidago. In: Hegi G (ed) Illustrierte Flora von Mitteleuropa, vol. VI (3.1.). Carl Hanser, München.

Weber E (1994) Evolutionary trends in European neophytes: a case study of two Solidago species. $\mathrm{PhD}$ thesis, University of Basel, Basel.

Weber E (2000) Biological flora of Central Europe: Solidago altissima L. Flora 195: 123-134.

Weber E, Schmid B (1993) Das Neophytenproblem. Dissertation Botanica 196: 209-227.

Zwölfer H (1976) The goldenrod problem: possibilities for a biological weed control project in Europe. EPPO Publication Series B 81, Paris. 